\title{
State Responsibility on The Eradication of Drug Crime
}

\author{
Oksidelfa Yanto \\ \{ dosen00240@unpam.ac.id \\ Pamulang University, South Tangerang City, Banten Province, Indonesia
}

\begin{abstract}
A criminal liability is an effort that must be performed as a form of state responsibility in the field of law against the act of distributing drugs by imposing legal sanctions. The facts show that in communities' life, drugs are used unlawfully, either by bureaucracy, students, academics, law enforcement and artists. The case of Jennifer Dunn had proved that drug abuse had occurred without interruption. The method that writer use in this research is normative research method with literature study approach. For that, the data that the authors use is secondary data related to the problems studied. The results show that drug trafficking occurs in many different ways and sophisticated strategies. National Narcotics Agency noted drug abuse continued to come and go. The state must be serious in dealing with drug issues. To impose a severe punishment by upholding justice must be done by the state,otherwise the drugs will ruin the life and future especially the future of the young generation which in turn can threaten the existence of this nation and state.
\end{abstract}

Keywords: Criminal act, drugs, state responsibility.

\section{Introduction}

The news about the arrest of celebrities caught consuming drugs (narcotics and dangerous drugs) seemed endless. Recently artist Jennifer Dunn was caught keeping or consuming drugs. The news about Jennifer Dunn and her drug is again making the life of celebrity homeland identical with the illegal goods. Why not, previously, in August 2017, an actor Tora Sudiro was arrested for possession of 30 dumolid grains. Tora is proven to abuse the drug without a doctor's prescription to be used as a sleeping pill. In July 2017, the legal apparatus also arrested Axel Matthew Thomas who had a Happy Five grain. In April 2017, an Indonesia Rapper Iwa K was also arrested by Soekarno Hatta Airport officers for carrying three rolls of marijuana that were inserted with other clove cigarettes.

Not quite up there, Ridho Rhoma dangdut singer was arrested for proven to have 0.7 grams of shabu (methamphetamine). He was rewarded 10 months in prison and rehabilitation 6 months 10 days. Of course, there are still many other celebrity names being captured and rehabilitated for dealing with drugs, as in 2016 there are Restu Sinaga, Gatot Brajamusti, and Imam S. Arifin. Even presenter Raffi Ahmad could also make a scene for people caught using methylone in 2013. The News of the arrest of drug abuse also occurred to law enforcement, government apparatus, academia to other communities, including children and adolescents.

In the context of drug trafficking, it is clearly seen today that the drug problem has become a very phenomenon in the life of the global community. Seeing the onslaught of drug abuse as a transnational crime is clearly a very real threat to the countries of the world. Imagine, the threat of drug trafficking is increasingly threatening the stability of security. Moreover, each ASEAN 
country already has a type of drug that is accompanied by a certain amount of raw material still until the form of drugs that have been in the form of processed such as heroin.[4]

By being spreaded of this network internationally and involving many countries, the United Nations (UN) defines the transnational crime as a form of violation in which its activities, its prevention efforts and impacts involve more than one country. The definition is reinforced by an understanding of trans-national concepts that can be defined as interactions between specific networks or groups that create relationships between individuals, groups of organizations and communities from different countries.[9]

From the above definition, the United Nations then identifies the crime of smuggling drugs into 18 transnational crime categories. Besides drugs there are also money laundering crimes, terrorism, theft of art and culture, theft of intellectual property right, weapon smuggling, aircraft piracy, land and sea piracy, insurance cheating, computer crime, environmental crime, human smuggling, trading of human organs, corruption and bribery.[9]

Even the crime of drug trafficking is recognized by the UN as a crime most considered serious and is in the first rank that must and have to be always wary of.Consequently, it refers to the legal system of Indonesia. Afterward it is no wonder that drug crimes in the Indonesian legal system are qualified as specific crimes, that its handling is also done specifically through special laws. This special arrangement due to narcotics crime is seen as a form of crime that has serious consequences for the future of this nation, destroying life and the future especially the younger generation, including children which in turn can threaten the existence of this nation and state. If the existence of this nation and state is threatened because of the danger of drug abuse, obviously drugs should not exist in Indonesia. Drug abuse must be eliminated or stopped by the state.

According to the National Narcotics Agency or BNN, that within the period of 2017, BNN (National Anti Narcotic Agency) has rehabilitated 1,523 drug abusers. The rehabilitation is carried out at the Rehabilitation and Correctional Institution (Prisons). In South Jakarta, in 2017 and BNN rehabilitation to addicts and victims of drug abuse as many as 188 people from the total amount of drug abuse as much as 209 people. Rehabilitation for drug abuse is increasing when compared to the year of 2016 that was as many as 172 people. Executive Summary of the 2016 BNN Survey on drug abuse and drug dark circulation in student and student groups in 18 provinces shows that the average age of adolescence for the first time taking drugs is 16 yearsold. However, some of them have already taken drugs at the age of 10 years and the highest 27 years old. As for the most reasons they found abusing drugs is a curiosity or trial and error for pleasure.

From the average age of drug abuse users recorded by BNN above, therefore until now the victims of drug abuse in Indonesia are increasing and not limited to teen age groups only, even those already in the age category of adult are involved in drug abuse. Various professions also come to use illicit goods called drugs. This is a bit ironic if seen from the profession that carried. A law officer even from the academics who should understand that the drugs are a type of illicit goods, it is instead misused for the benefit for a moment. They should set a good example to the community.

In fact, in the development of drug abuse cases, the perpetrators are not only from among those who have sufficient financial resources. This is considering the high drug prices. Drug abuse also comes from those who cannot afford it. Drugs have also penetrated the low societal society. It is ironic indeed, whereas in the teachings of any religion in the world it is forbidden to commit acts contrary to religious values. In Islam human beings are prohibited from approaching drugs. Steer clear of drugs is a way of humanity practice his religion well. This is what the religious community should understand. For any religion on earth Indonesia will 
always bring its people into good condition, away from all the problems that make people being suffered. It's just how human beings run their religion according to the orders and restrictions in the religion. If religion is executed in accordance with the commands of God the Almighty, therefore human life will be better.

A Muslim is commanded to practice Islam comprehensively (kaffah) in everyday life. A Muslim must carry out all aspects of Islamic teachings that include human relationships with Allah, relationships with fellow human beings and their environment, and relationships with himself. Thus, when a religion is sullied or there is contempt, then someone or some who do so will be punished according to existing criminal sanctions.

A Muslim, especially the youth must be able to run the Shari'a of Islam properly and correctly in accordance with the demands of the Qur'an and hadith. Youth must keep their soul and nature. If seen, the case of drug abuse of the victims and the perpetrators also originated mostly from young people of age. Most young victims, even perpetrators of the many uses and distribution of drugs in society. The role of community leaders, ulama, and stakeholders in Indonesia should be able to prevent moral decadence among the youth.

In the history of the great Prophet Rasulullah Shallallahu'Alaihiwa Sallam, the Prophet RasulullahShallallahu'AlaihiwaSallam preach the youth wisely. The method employed by the Prophet as a preacher is to safeguard the nature and soul, to deepen, refine the emotions and feelings of human beings, to balance ambitions with values and to build upon the beliefs of young believers in carrying out their leadership tasks to foster the potential of hidden resources.

The ways of the Prophet Rasulullah Shallallahu'Alaihiwa Sallam should be imitated by the stakeholders in this country. Mainly the role of ulama. If the ulamas are broken, then the damage spreads and flows into the body of the ummah(human being) therfore it will happen what has happened. The ummah(human being) were then struck by great disasters and slanders, while their righteous religion became dead objects lying in books like mummies stored in an old museum.[4]

For this reason, in terms of high circulation and drug use in the community, legal protection efforts against victims of narcotics abuse need to get attention, because the victims of narcotics abuse are mostly young generation who are weak in identity. Due to the search for the identity there are many teenagers who fall into drug abuse. It should be, under any circumstances, the younger generation should get protection, because the younger generation is the successor of the nation, thus need to salvage the younger generation.

One of the protection and rescue of the young generation or society in general from the dangers of narcotics is to provide the maximum penalty to the perpetrators in accordance with the provisions of existing legislation. It is undeniable that the protection of the law is born from a rule and the provisions of the law, and all laws and regulations made by the state, is basically a manifestation of the existence of the state to enable the law to regulate the behavioral relationship between members of society to become a peaceful society, tranquil and far from the violations of the law. This nation must agree, that drug offenses must be viewed as a form of crime that has serious consequences for the future of this nation. Drug crimes have damaged the future of this nation and nation generation. Only a country that has the responsibility and ability to address it. Countries with all components and the existing legal apparatus has been come to time to stop the high circulation of drugs in the sphere of community life. 


\section{Literacy Reference}

Consequently, the perpetrators of drug dealers and abuse should be given legal sanction in accordance with existing laws by the state or law enforcement agencies. Especially when this drug abuse has reached the students. In Law No. 35 of 2009 concerning Narcotics there is a goal to be achieved that is to protect children as the nation's generation to be free from the circulation and abuse of narcotics.[2] In order to realize a legal state, It is not only required legal norms or statutory regulations as legal substance, but also required the institution or its driving agency as legal structure supported by legal behavior of all components of society as legal culture.[7] The norm of law can come from religious norms, norms of decency and moral norms. A provision in religious or moral norms may be established or elevated as the legal norm of the state therefore it creates strict rules and sanctions. Legal norms can also create their own norms that did not exist in all three norms, such as the rules of the law of traffic. [15]

As a state of law, all national issues must be resolved through legal system, including drug abuse issues. Do not let again the law is ignored its meaning. Ignoring the legal norms in the eradication of drug crime is the same as ignoring the principle of Indonesia as a state of law. The principle of Indonesia as a state law has the same goal of creating certainty, justice and legal benefit. When a state law occurs a waiver of the legal objective therefore the slogan as a rule of law is paper decorative only, but minimal implementation.

\section{Expert Opinions}

Mr. Susanto a lecture Magister of Law said that, from the news about the arrest of the celebrities above and the number of people caught consuming and abusing drugs, it can be ascertained that the state of Indonesia is one of the countries that are very vulnerable in smuggling and trafficking ofdrug. The alternation of the victims and the perpetrators arrested by law enforcement proved such a thing. Various strategies to eliminate drugs are done by the syndicates. Whether by air or sea transport.[17]

While Mutiara Hikmah in his writing said the strategic position of Indonesia's territorial waters places Indonesia in a very important palce for countries of various areas, which has beneficial impacts and simultaneously threatens the interests of the Indonesian nation. This many result in serious issues related to security, legal, economic or national defense sectors. [8]

Even the National Narcotics Agency (BNN) notes several strategies and modes used by drug smugglers in Indonesian territory, such as; swallowed in body parts, food places, in suitcases of clothing, toothpaste, furniture, souvenirs, and also through postal or shipping services.

By using various modes and strategies as mentioned above, then it is visible a potential to develop networks and syndicates of drugs circulation always appear in many faces. The network of drug crimes is controlled by organizers who are so solid, both national and international networks. In launching its action, the organization works very carefully, quickly, neatly, broadly, and certainly strictly confidential and involves many countries. This is known as the international drug network. Those who target the Indonesian market. They are attracted to Indonesia because of the high and increasing number of drug users. 


\section{Discussions and Results}

In criminal law it is recognized a criminal responsibility to a person or some persons who commit a crime. A sanction shall be granted if the person committing the criminal act does not apply to him or her anything that remove the criminal. This indicates that the imposing the sanctions in criminal law is not merely aimed at retaliation to any person committing a crime.

Accountability in criminal law is contained in the provisions of special criminal law and general criminal law. Nevertheless there are differences in the implementation of the judiciary on various existing criminal acts. In special criminal law, for example, if there is a crime that occurs, it will be heard in a special court which is handled by a special law enforcement. For example, if there is a corruption case, it will be settled by the court of corruption. Likewise with other special criminal cases, for example the case of juvenile justice. Will be handled by the juvenile court with a special judge of the child.

In imposingthe sanction, therfore the criminal law will have high functionas a means of tackling crime or as a social control (community control). The imposing of criminal sanction should have more benefit, because if a criminal sanction is imposed with the sole purpose of retaliation and frightening therefore it is not certain that the goal will be achieved, because in the defendant does not always arise any feeling guilt or regret, maybe even put a sense of resentment. In a criminal law a person can only be subject to criminal sanctions if in his actions there are elements of against the law and the guilty.[10]

Actually, if we talk about criminal liability, then this term is more focused on the existence of punishment for anyone who commits a crime. This means, when a person performs an act and the action has an element of action against the law or element of guilty, subsequently the perpetrator can be asked for criminal responsibility. So the accountability will then determine whether a person who commits an act can be given the status of the suspect or defendant. This status can be loaded if his actions can be accounted for a criminal act that occurred. A general understanding of criminal responsibility can be seen as a person's accountability of a crime he or she has perpetrated. Thus it is clear to us that what is accounted for someone is a crime or a criminal offense he committed. Being able to be punished of anyone shall depend on whether in that person there is no element in him that makes him can not be punished.

Thus, the occurrence of criminal liability is because there has been a crime committed by a person. On condition that a person committing a criminal offense may be punished if the offender is able to account for the deeds he or she has committed. If a person, even if he has committed a crime, but if his mind and soul are unhealthy, then he cannot be sought for criminal liability. As explained in Article 44 of the Criminal Code; "A person cannot be criminally accountable if a psychiatric defect or suffering from illness".

From this formulation can be determined the conditions included in the provisions of Article 44 namely; First, to have a soul that does not grow perfectly or the soul of a person is disturbed by any deseases, what is meant here is because of the state of the thinking power of the perpetrator, he cannot be reproached in such a way that it is appropriate that he is not subject to punishment. In this case it takes experts such as a specialist and a psychiatrist. Secondly, the extent of the disease must be in such way therfore his actions cannot be held accountable to him. However, if we try to find a provision stating how / when a person is deemed not to have a healthy soul it will not be found, so to determine this we must again see Memorie van Toelichting (M.v.T) or an explanation of the Criminal Code. If a person cannot be held criminally liable for his action, therefore such person cannot be punished. Although there are unlawful acts committed. 
In addition to Article 44 of the Criminal Code, there are also articles that remove the criminal for the perpetrators. Such as; in Article 49 of the Criminal Code on forced defense. That is the circumstance in which a person commits an act that is prohibited by law because of a serious threat that may harm him or others, to the honor of decency or property of himself and others. It is also contained in Article 50 of the Criminal Code, which is done for carrying out the law. For example: executor of dead shot. Then Article 48 of the Criminal Code on constrained. "Whoever commits an act of being forced by any unavoidable power shall not be punished".

From the description of Article 44 of the Criminal Code above, then If the perpetrator is disturbed his soul, he cannot be sought for criminal responsibility. As the reference in the Criminal Code. Therefore, in general crimes and violations of Indonesian criminal law, clearly will be guided by the Criminal Code. Because the Criminal Code is an effort to uniform the criminal law that can be used as a basic reference in criminal punishment that can be applied to all people without exception. Similarly, the provisions on who can or cannot be prosecuted, the conditions of a person can be punished and how long the sentence will be imposed.

\subsection{Various Efforts made by the Government in the Eradication of Drugs}

In addressing the rampant circulation of drugs in the community, the government has made various efforts such as providing socialization to the community continuously. Moreover, the government is also always seeking rehabilitation to victims of drug abuse. And the more extreme again, the government through the law apparatus has dropped a death sentence to the perpetrators of narcotics dealers. With the death penalty imposed on drug abusers, it does not mean that illegal drug trafficking is reduced in the midst of people's lives, but rather the opposite. Drug abuse takes place on a very remarkable scale. The perpetrators can be from among students, students and even government officials even do not miss tasting illicit goods called drugs.

In order for the government's plan to eradicate illegal drug abuse can be maximized and make the State of Indonesia free of drugs then it is necessary for the government to socialize continuously to the community. Socialization is not only in the form of an appeal but must also be done persuasive approaches by directly coming to the community, ranging from neighborhood level to village level even to sub-district, district / city and provincial levels. The government can invite the community to always mobilize awareness of the dangers of drugs by establishing anti-drug movement post. In every post formed by parties such as the head of the RT or the head of the RW, even community leaders and youths shoulder to shoulder to provide enlightenment and counseling to the public about the dangers of drugs and how severe the threat of punishment will be imposed for anyone who tries to abuse drugs. In order for the established posts to be controlled by the community, the government should pay attention to the attention of the people who are willing to spend their time to take care of the existing posts, so they in daily life always increase the spirit in striving to eradicate drugs as a form of responsibility to the community and government. It is no less important to do by the government according to the author is the government should always involve the mass media, either print or electronic. Mass media will be able to convey messages of goodness in the form of anti-drug appeals. Of course the message and the appeal is packed with a good and easy to understand language style, so that people can understand well what ispresented. The government should also always create the potentials that exist in various regions. Improving skills to the community with all the natural wealth that exists will bring the sources of sustenance to sustain life. Then no less important, the state must always do cross-border cooperation both bilaterally, regionally and internationally. Cooperation, especially in terms of law enforcement and how to eradicate it. 


\subsection{Criminal Accountability against Drug Crime}

Crime is a criminal act that is heavy of its threat of punishment. The threat of a criminal punishment may include a fine, a jail sentence of several years, a life sentence and a death sentence, and sometimes a penalty for confiscation of certain items and the revocation of certain rights and the announcement of a judge adjudication.[1] The perpetrators of crime in the Indonesian criminal justice system have a very significant impact on the social life of the community. The perpetrators of the crime are often troubling the community. Moreover, the current patterns of crime are increasingly sophisticated and continue to grow as a result of the community affected by the surrounding conditions. People are afraid to do social activities, because there are crimes that target beside them. Even that the criminal justice system is overwhelmed in overcoming it. As a result many crimes that are not finished. This condition is of course understandable by some people because the unequal amount of legal case completion with the level of crime committed in the community. However, on the one hand the community certainly does not care about it. The community only understands that every crime must be settled well by the law apparatus so that people's living can be peaceful and far from the threat of crime. If the crime is not resolved properly, this will create a sense of disappointment in society, because society is not satisfied with the services provided by the existing apparatus. This is the challenge of the existing criminal justice system.

The practice of criminal justice is often unsatisfactory to the victim not only because the perpetrator of the crime that harms him or herself is acquitted by the court or the judge's sentence is not worth the suffering that the victim suffered. But also due to the treatment received by the victim from the criminal justice system apparatus which is sometimes inhumane to the victims, especially when giving testimony about the criminal acts that suffered so as to increase his suffering.[14]

The proceed of the criminal justice system that is in compliance to the expectations of the people will certainly satisfy the justice seekers, and that means the real purpose of the law will be achieved. The principle of legal state is none other than to uphold the purpose of the law in order to achieve the era of welfare in society. Therefore, legal objectives such as certainty, fairness and legal benefit must be implemented starting from the lowest level of law enforcement to the highest level. In a society that upholds the law, the issue of the ordinance of realizing the goal is as important as the goal itself. The goal of bringing about justice can only be achieved in fair ways. These means include elements of institutional certainty, mechanisms certainty and various predictable outcomes. This is the day-to-day mentioned as legal certainty. Indeed certainty is not the same as justice, maybe even the certainty can be contrary to justice. In relation to narcotics crime, the intended purpose of the law must be properly implemented. Because the crime of narcotics is a very extraordinary crime of its mode and development. This crime has damaged the young generation of this nation.

If seen in the context of narcotics crime, then the narcotics crime has transnational nature. This crime is also committed by the younger generation of the nation that is very endanger the lives of people, nations and the State. Narcotics crime is a special crime stipulated in its own regulatory provisions. The use of special criminal law terminology gives the entity that in the criminal law system other than the study of general criminal law (ius commune), there is also a special criminal law review. This terminology is not sudently made by jurists or legal experts but has a specific purpose. One of its purposes is to distinguish from the general criminal law which is often referred to as codification criminal law.[13]

For criminal acts of drug abuse, there is a law number 35 of 2009 on narcotic criminal acts that provide criminal penalty. This law explains the criminal penalty for anyone found to be 
abusing drugs. Criminal or punitive threats can be imposed with capital punishment. This criminal punishment is the heaviest of all sentences such as life sentence or twenty years in prison. So if any whom produce, supply, assemble and so forth a kind of drugs may be punished by death penalty fines as amount to one billion rupiah. Drug abuse, if the offense is initially commenced with an evil conspiracy, the perpetrator shall be subject to capital punishment or for imprisonment. Drug abuse, if the offense is initially commenced with an evil conspiracy, the perpetrator shall be subject to capital punishment or for imprisonment. In contrast, if a drug crime is committed in an organized manner that is very neat and encompasses a very wide network, then the perpetrator may be punished by death penalty .

Seeing the criminal threat to drug abuse above, actually it can make people afraid to commit acts of drug abuse. There are still without rights and unlawful acts that is by intentional carrying and sending, transporting Narcotics with Group I types. Therefore, because the circulation of drugs network is very broad and organized neatly, the perpetrators are given very severe punishment. This is in order that the perpetrator can feel the deterrent effect. But in practice, the penalty imposed is still not much that makes the deterrent. The proof, the perpetrators came and went. For that, it is time for the State to pose a very serious threat of punishment. In order for the act of distributing and marketing or transmitting drugs do not continue.

\subsection{State Responsibility to Drug TraffickingCommits}

The handling of crime of drug trafficking requires special and serious attention. This is because the impacts arising of its misuse are not only health problems, but also to the social, security and economic of the country, which in turn will affect the stability of the state. Special and serious handling is also due to the strategy of trafficking and drug smuggling by syndicates that are already so severe with various ways and modes. Therefore, the state through the law enforcers such as police, prosecutors and courts to combat drug trafficking must make extraordinary efforts. Among the efforts that can be done by the state is by giving the most severe punishment for the perpetrators of criminal acts of drugs. The heaviest punishment is the best way for this state to be free from the drug. Because the law is the commander who will control all the problems that occur. If the law is upheld properly and correctly, subsequentlyall existing problems will be resolved. So let's uphold the law to eradicate drugs to their roots.

Among these instruments are police, prosecutors and courts. Therefore, the state through law enforcers such as police, prosecutors and courts should make tremendous efforts in combating drug trafficking. Among the efforts that can be done by the state is by giving the most severe punishment for the perpetrators of criminal acts of drugs. The toughest punishment is a form of state concern for the protection of human rights (HAM) to every society. No more people affected by the dangers of drugs. Thereforeimpose the heaviest punishment to anyone who plays with drugs. In fact, only a country with all the power and authority that has the ability to impose the heaviest punishment to the perpetrators of narcotics dealers and the like. Violations can also occur in cases of dimensions of social and cultural education, health, the right to housing. It says violations if the state is unable to meet the minimum requirements. For example, the number of unemployment that reached 8 million people led to the Indonesian government is required to gradually reduce the amount in accordance with the ability of the state. However, if the state fails to perform these obligations then the government is considered to have violated human rights. This model of settlement of violations of the Covenant issue in Indonesia is not yet available, so that people who wish to demand the fulfillment of this right can not do so directly to the court. What the community can do is to ask non-governmental organizations to advocate for the interests of the people themselves or in the Indonesian context by reporting to the National Commission on Human Rights (Komnas HAM) which has a 
function of monitoring the implementation of human rights in Indonesia. Thus, human rights violations are different from criminal offense (crimes). Human rights violations occur when a person performing an obligation on behalf of a position as a state organizer violates basic human rights. Basically the accountability of perpetrators of human rights violations is attached to a person in the name of office.[12]

In a democratic country, a good government is a government that fully guarantees the interests of the people and the basic rights of the people. In addition, the government in exercising its power needs to be limited so that the power is not abused, not arbitrary and really for the benefit of the people. Power needs to be limited, because it tends to be abused.[15] The state provides protection to the citizens is an obligation. The main promise of the state to its citizens is the protection of their security. The extent to which a country can fulfill this promise always varies greatly depending on its mastery of power resources.[5]

In order for the state not to allow human rights to be neglected by the number of victims of drug crimes, the punishment for drug abuse must be firm. So many articles governing the toughest punishment for drug traffickers. There is even a threat of capital punishment. The death penalty is believed to have a deterrent effect. During this time, sometimes someone who circulates drugs will tend to repeat his actions after he was released from prison. The perpetrator has not been deterrent after he was put in jail. From that, so as not to repeat the crime committed, then the death penalty is a way to overcome it. In the context of the imposition of capital punishment for the perpetrators of drug crime, then in Indonesia is still referring to the Criminal Code (KUHP) which is a Dutch Colonial legacy. As a matter of fact in the explanation of Article 11 of the Criminal Code, the execution of capital punishment can be executed by trapping the perpetrators in the gallows. After that, the executioners dropped the board where the convicted was standing. The execution of capital punishment in the course of its history is sometimes considered to be contrary to the principles of human rights. Thereforethe ways in which respect for human rights are abandoned and replaced in more human ways. Formerly the execution of death penalty in some countries there are buried bodies on the ground and his head outside, then thrown in a crowded manner. This is considered inhuman. Many other ways, which are then opposed by many parties. Some countries have even abolished the death execution in the country. In Indonesia, then later with the enactment of Stablaad of 1945 Number 123, which in the end capital punishment carried out by shooting dead convicted. This Statblaad is reinforced by Law Number 2 / PNPS / Year of 1964, State Gazette of 1964 Number 83, (stipulated as Law Number 5 of 1969) stipulating that the execution of capital punishment is changed by shot dead.

The imposing of death sentence, jurisdically is the authority of the court in this case the judge to implement the provisions of legislation for the sake of law in Indonesia. Although the imposition of capital punishment on drug offenses sometimes leads to pros and cons. Accordinglyit is not wrong that the article on the death penalty for drug cases ever requested material reviewing of the 1945 Constitution (the 1945 Constitution) through the session of the Constitutional Court (MK). The proposal was found in Case No. 2-3/PUU-V/2007 on the existence and appropriateness of capital punishment to be applied in Indonesia. The constitutional panel of judges in the material review of the article, clearly illustrates that the application of capital punishment is still appropriate and appropriate to be applied in Indonesia. Cause of drug abuse in Indonesia in the emergency condition of narcotics.

Subsequently, the Constitutional Court's decision becomes one of the sources of law because it is final and binding. Such decisions shall be published in the State Gazette within a period of no later than 30 (thirty) working days after the decision is made in a plenary session open to the public.[3] 
This means, smuggling and abusing thedrug includes in serious crimes. In the case of imposing the capital punishment for perpetrators of serious crimes, the judge usually handed down the death penalty based on the existence of human rights violations which in this case is done by the drug dealers to the community, especially the young. Many drug addicts among young people are difficult to cure. Even if healed usually will come back again as a drug addict. Drug addicts will do everything they can to get drugs, even drug addicts tend to commit a crime. For the addict who is still a student, will usually lower the spirit of learning and in the end the overall learning achievement will decline. In the end, the leadership of the nation by the younger generation will be extinct and this is dangerous for the future of the Indonesian nation.

In imposing the death penalty, a judge must be charged with caution, because it involves a sense of community justice. Judgments made by a judge should be based on a conscience to enforce the law for a drug offense. Judges on the basis of their verdicts must protect the public, especially the children from the threat of drugs. If the judge executes the verdict properly, then the judge has had a sense of humanity and social concern in protecting human rights.

In this case, Wignyosoebroto suggested that the judge's performance paradigm in developing countries with a pluralistic culture like Indonesia should be corrected and be amended. Judges are no longer limited to existence as a funnel that echoes and hides some statutory sentences. Judges are not also tools designed for logic and mechanical performance, but complete human who have sensitivity to humanity and social concerns.[16] Certainlyit is not the judge required so, all law enforcement officers must be qualified and have social awareness. If the above is carried out by law enforcement officers, namely the qualified law that is run by law enforcement according to their respective profession in the existing criminal justice system, in the forthcomingthe citizens will be free from the dangers of drug abuse.

This is in accordance with the ideals of legal reform that provides certainty, justice and benefit to the community. Ultimately, legal reform is directed to provide a basis for the changes and growth of excellence economic, political, and government system. So that gave birth to the system of nation and state is also excellence.[6]

For every law enforcer who has integrity, it is applied that the profession must be run on two ethical demands. First, it must be carried out responsibly where the responsibility has two directions, that is work and the result must be qualified, and consequently in other human beings always need to be considered, or in other words should not harm any third party. Second, for the noble profession is demanded more, that is the free attitude of self-interest, the client/patient's interest must take precedence over personal interests; and the demands of professional ethics must be maintained, even if the client of society, religion or state desires another.

In addition, in the face of the rampant cases of drug trafficking, the government together with religious leaders and community leaders should always give positive things to all citizens of society. The positive things referred to is that the government to always protect the ethical and moral of every citizen. The government must continually socialize that so dangerous drugs for the future and life. So in the future, people can distinguish what is good and what is bad. Which are allowed and which should not be done.

Talking about the difference between good and bad is, in essence very vague, because if something is not good, then it is bad. The degree of evil is not the same, there may be a very bad one and a bit bad, but in fact it's all bad because it is not good. From the description, it can be argued that it is said to be good when givingfun, pleasure, satisfaction, as expected, while bad if judged otherwise.[11] Human being has been conferred by the Lord of intelligence and religion as the source of moral teaching. By his intelligence, human can distinguish which one 
is good and bad attitudes. Therefore, human freedom has a close relationship with morality. With good morality will make the law run well in the middleof community life.

Since the law is present in the life of the community created by the state to give benefit, therefore the execution of the death penalty for the perpetrators of drug crimes in Indonesia must be implemented by the state with reference to the provisions of existing legislation. This psychological punishment clearly brings a deterrent effect to the perpetrators and will also have a positive effect on the development of drug trafficking in Indonesia.

\section{Conclusion}

Drug problems can not be allowed to continue rampant. Therefore the form of criminal liability for the act of distributing drugs by the perpetrator is a jail sentence. This imprisonment is given due to the deliberate element of the perpetrator. In this case, the offender is in a state of healthy mind and soul in the distribution of drugs. Usually the purpose of the perpetrator to distribute is to gain profit, both personally and in groups, but sacrificing the lives of others. What is done by drug dealers there is a guilty, and the guilty requires the ability of criminally responsible to the perpetrators.

It becomes very important to do in the future i.e.the law enforcement strategies implemented by the state, such as the police and the National Anti Narcotics Agency to always prioritize and focus the war against drug syndicates, both nationally and internationally. Then the state must impose severe punishment on the perpetrators who distribute drugs by upholding justice. This is because drugs have damaged the lives and future of society, especially the future of the young generation which in turn can threaten the existentiation of this nation and state. The punishment that can be imposed by the state is punishable with a maximum imprisonment of 20 (twenty) years or life imprisonment or capital punishment.

\section{References}

[1] Ali, Zainuddin, Penggantar Hukum Indonesia, Ciputat: Yayasan Masyarakat Indonesia Baru, 2015.

[2] Andriyani, Fepry, M. Nur Rasyid, Mohd. Din, Pemenuhan Hak Rehabilitasi Narapidana Anak dalam Kasus Narkoba Di Aceh, Syiah Kuala law Journal, Vol. 1 (2), Agustus 2017.

[3] Aryanto, Jesi, Legitimasi Hukuman Mati Di Indonesia dalam Kaitannya Dengan Hak Hidup, Jurnal Hukum Adil, Vol. 2, No. 2, Agustus 2011.

[4] Anggraini, Devi, Suatu Kebijakan Asean dalam Menanggulangi Penyalahgunaan Narkoba di Asia Tenggara, Jurnal Analisis Hubungan Internasional, Vol. 5 No. 3, Oktober 2016.

[5] Faulks, Keith, Sosiologi Politik Pengantar Kritis, Bandung: Nusa Media, 2010.

[6] Gunawan, Herry, Kepada Bangsa: Refleksi Kerisauan Seorang Sulastomo, Jakarta: Penerbit Kompas, 2000.

[7] Hastuti, Sri, dan Lasmaida Limbong, Pengukuran Kepuasan Masyarakat Terhadap Kinerja Kejaksaan Dalam Penanganan Perkara, Jurnal Bina Adhyaksa, Vol. 6, edisi 3, Juli 2016. 
[8] Hikmah, Mutiara, Illegal Fishing In Indonesia From The National And The International Law Perspectives, Indonesian Journal of International Law, Volume 11 Number 1, October 2013.

[9] Kartaatmaja, A.M, "Menuju Asean Bebas Narkoba 2015: Situasi Penyalahgunaan Narkoba Di Indonesia”, Jurnal Aspirasi, Vol. 5 No. 1, Juni 2014.

[10] Latif, Abdul, dan Dey Ravena, Analisis Yuridis Pungutan Liar Biaya Parkir yang Dilakukan oleh Preman Di Kota Bukittinggi Dikaitkan dengan Kitab Undang-Undang Hukum Pidana, Prosiding Ilmu Hukum SPeSIA, Vol. No. 2 Agustus 2016.

[11] Mardani, Etika Profesi Hukum, Depok: RajaGrafindo, 2017.

[12] Riyadi, Eko, Hukum Hak Asasi Manusia, Perspektif Internasional, Regional dan Nasional, Depok: Rajagrafindo Persada, 2018.

[13] Satria, Hariman, Anatomi Hukum Pidana Khusus, Yogyakarta: UII Press, 2014.

[14] Suseno, Sigid dan Nella Sumika Putri, Hukum Pidana Indonesia, Bandung: Remaja Indonesia, 2013.

[15] Sisman Putra, Wandhi Pratama, dan Ruslan Rauf, Pendidikan Kewarganegaraan Bingkai NKRI, Jakarta, Mitra Wacana Media, 2016.

[16] Wignyosoebroto, Soetandyo, Mempersoalkan Keadilan dalam Amar Putusan Hakim dalam Wajah Hakim dalam Putusan: Studi atas Putusan Hakim Berdimensi Hak Asasi Manusia, PUSHAM UII, Yogyakarta, 2010.

[17] Dr. Susanto.,SH.,MH, The Advokat and Senior Lecture of University of Pamulang, South Tangerang City, Banten.

\section{Legal Documents}

20. Law Number 48 of 2009 concerning Judicial Power.

21. Law Number 35 of 2009 concerning Drugs Abuse Crime.

22. Law Number 8 of 1981 concerning Book of Criminal Procedure Code.

23 Law Number 2/Pnps/Tahun1964 concerning the Procedural of Capital Punishment Execution imposed by the Court in Public and Military Judiciary. 